\title{
INVESTMENT CLIMATE EVALUATION AS AN EFFECTIVE DETECTION METHOD FOR NEGATIVE IMPACTS ON COUNTRY'S DEVELOPMENT
}

\author{
Anastasiya Ilyina ${ }^{1}$ \\ Kyiv National University of Trade and Economics, Ukraine
}

\begin{abstract}
The purpose of the paper is to determine the procedure for calculating the investment climate favourableness and, based on its findings, study the nature of the investment climate in Ukraine. Methodology. In the paper, there were used the following methods: the dialectical method (understanding the investment process and its characteristics as the investment climate components); scientific abstraction, theoretical and empirical analysis (characteristics of the investment climate components and definition of their interconnection based on the corresponding scheme); method of modelling (guiding the formulas for calculating the main investment climate components based on generalizing the theoretical research studies of Ukrainian and foreign researchers); method of system analysis (defining issues of the investment climate favourableness in the country as an integral economic system on the example of Ukraine); statistical methods (grouping, comparison, dynamic series), used in the study of dynamics of main indicators of economic and social development of Ukraine, on the basis of which the dynamics of the calculated ratio of the investment climate favourableness in Ukraine was analysed. Results of the research study showed that the investment climate is determined on the basis of the ratio of the investment supply and investment demand. The supply of investment resources is an attractive factor for both national and foreign investors in one or another branch of economy, determining the level of investment risks, on which depends the socio-political and economic security of investors. At the same time, the investment demand characterizes the investment intensity level, which reflects the growth rate of investment inflows into one or another branch of the country's economy. An excess of the investment demand over investment supply in the country reflects the unfavourable investment climate of the country due to the lack of incentives for investment recipients to implement investment projects, and also unregulated interests between the subjects of investment process (state, potential investors, and recipients of investments). In Ukraine during the period from 2012 to 2016, the investment climate was unfavourable, as the ratio of the investment climate favourableness was significantly lower than the threshold. Practical implications. The calculation of the country's investment climate favourableness is necessary to be made in order to reflect the effective use of indicators of economic and social development by the state. It is to say the efficient allocation and distribution of the gross domestic product, based on indicators of the amount of wages of hired workers and amount of net taxes on production and imports. According to the appropriate situation, the state should develop a budget plan for the next year with the benchmark for allocating budget expenditures in some sector and providing investment support. In Ukraine, the improvement of the investment climate requires the introduction of changes in tax legislation regarding the privileges for certain types of investors and innovation-active enterprises, and also provisions defining the transparency of the investment process. Value/originality. The ratio of the investment climate favourableness $\left(R_{1 C}\right)$ should be at least 0.1 , where $R_{1 C} \geq 0.1$ means that the investment climate is favourable, $R_{\mathrm{I}} \geq 0.1$ - neutral, $R_{\mathrm{IC}} \leq 0.1$ - unfavourable, considering that the threshold of the investment attractiveness level $\left(L_{\mid A}\right)$ is $10 \%$, investment intensity level $\left(L_{\|}\right)-100 \%$.
\end{abstract}

Key words: investment climate, investment process, investment attractiveness, investment intensity, tax burden, economic and social development.

JEL Classification: E22, H21, 011

Corresponding author:

${ }^{1}$ Department of Economic Theory and Competition Policy, Kyiv National University of Trade and Economics.

E-mail:nnnasta@ukr.net 


\section{Introduction}

In recent years, the economic crisis in Ukraine has had a fairly negative impact on the investment potential of the national economy and almost halted the activities of innovation-active business entities. Despite the fact that in Ukraine the amount of invested funds in the certain branches of the economy is constantly increased, the innovation infrastructure remains undeveloped, the process of job losses is accelerated, and standard of living is decreased. It means that the environment of the investment process of the country has a number of negative factors creating risks for potential investors to incur losses from investing in the implementation of investment projects, especially with long-term and innovation character. Due to the factors slowing down the pace of the implementation of investment projects, in particular, a high level of budget deficit, high tax burden, absence of tax privileges, which also cause enterprises to be unable to effectively carry out innovation activities by slowing down the process of acquiring new fixed assets, the attractiveness of Ukrainian economy for potential investors is still at a low level. All of this creates a situation where the subjects of investment process have a disagreement on the execution of investment contracts, resulting in a conflict of interests between them, which complicates the process of investment projects implementation and causes unfavourable climate for both investors and recipients of investments. Some Ukrainian and foreign researchers, in particular, A. Damodaran (2012) proving the interconnection between the investment attractiveness and investment intensity, B. Erlen and A.J. Isaak (2015), studying the investment intensity as one of the key factors in the efficiency of investment, Y.V. Nefyodova (2010), studying the direct relationship between the investment process and investment climate, L.S. Valinurova, O.B. Kazakova, and E.I. Iskhakova (2012), considering the components of investment attractiveness and some others did not leave aside the issue of improving the investment climate. However, the question of resolving conflicts of interests between the subjects of the investment process in order to improve the investment climate in Ukraine remained open. Thus, the issue related to the investment climate remains relevant and requires further research.

\section{Characteristics of investment process elements forming investment climate}

The investment climate is a complex of objective economic, social, political, and legal conditions for implementing the investment process at all levels of management on the principles of effectiveness to raise the investment attractiveness of the economic system, processes and economic life's phenomena of which can take place both within a separate region, industry and/ or enterprise, and country as a whole (Fig. 1).

So, depending on the internal (development of the competitive environment of entrepreneurship; level of involvement of the population in the investment process; relations between the state and regional

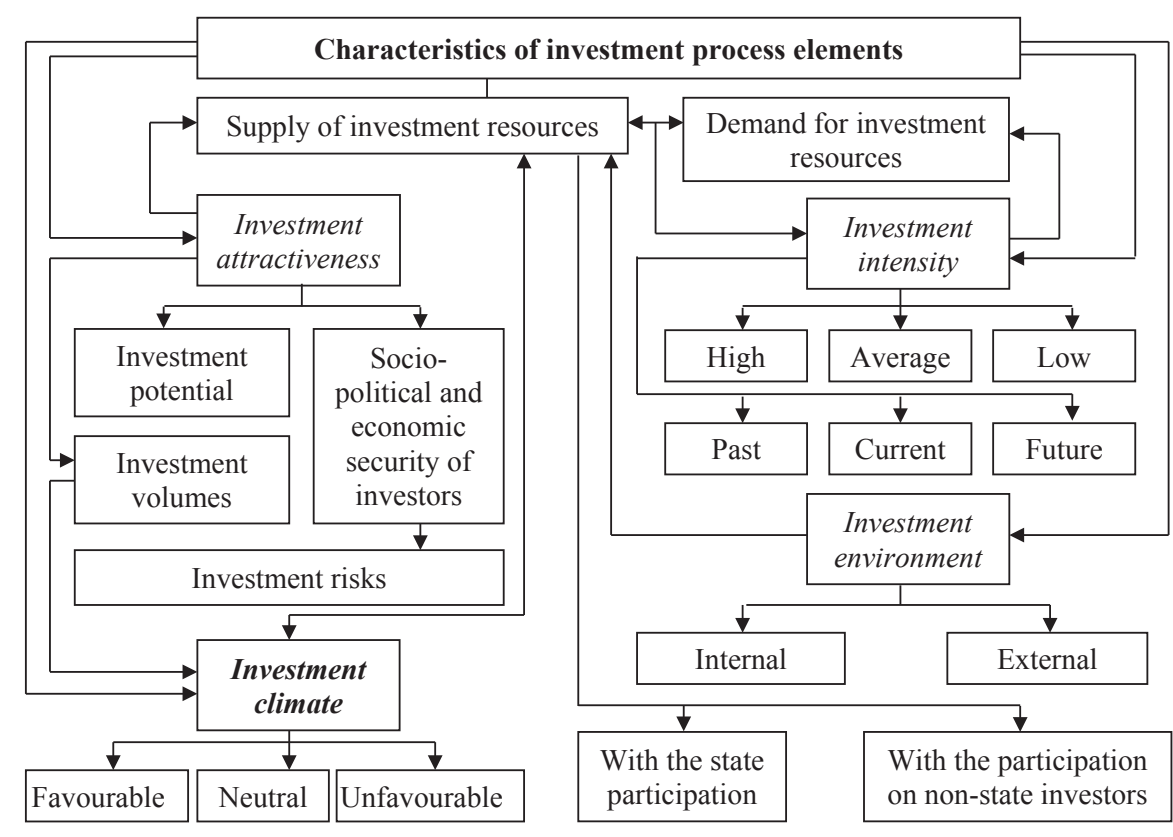

Fig. 1. Interconnection of content elements of investment process as the investment climate components

Source: the author's research on the basis of (Grynyova, Koyuda, Lepeyko \& Koyuda, 2008; Gulyaeva \& Ryabchenko, 2012, p. 23; Nefyodova, 2010; Valinurova, Kazakova \& Iskhakova, 2012, p. 16) 
authorities; attitude of authorities to foreign investors; access to foreign currency loan and so on) and external (wars, bioclimatic conditions, fires, accidents, building collapses and so on) factors of influence on the investment process, the investment climate forms the investment environment, which is divided into internal, dependent on the state and can be changed by it, and external, independent of the state.

Depending on the situation in the investment environment, the investment climate is divided into: favourable, characterized by a low level of risks of the losses from investment activities (investment risks); neutral, when the level of investment risks is moderate, and unfavourable because of the high level of investment risks.

In turn, the investment environment forms the investment attractiveness, which is determined by the supply of investment resources for potential investors and includes a number of indicators of the economic and social development of the country, namely: gross domestic product and its components, consolidated budget deficit, capital investments, including investments at the expense of the state and local budgets.

So, the investment attractiveness is a collection of objective features, properties, facilities, and economic opportunities that determine the effective demand for investments in it, i.e. investment intensity. Substantially impacting on the investment intensity, which also depends on the state's regulation of investment environment, the investment attractiveness reflects the assessment of subjects of the investment process, on which depend the socio-political and economic security of investors, and level of their capacity, i.e. investment potential.

The investment potential is a material basis for ensuring the economic growth and social development, indicators of which reflect the sufficient level of available investment resources provided for both investment in high-yield objects and covering unforeseen losses from investment activities, the probability of occurrence of which is determined by the level of investment risks. Under such conditions, the investment potential is characterized by the economic possibility to provide maximum yield or minimum risk level for a given period of investment (Damodaran, 2012; Gulyaeva \& Ryabchenko, 2012; Nefyodova, 2010).

The investment intensity determines the demand for investment resources and is characterized by the intensity of investments for a certain period, which depends on the investment volumes and its efficiency. As a rule, it is divided into three levels: high level, when the growth rate of investments is higher than normal; average level, which reflects the unchangeable growth rate of investments in two periods, and low level, which is identified as a decrease of investments (Grynyova, Koyuda, Lepeyko \& Koyuda, 2008; Mayo, 2014; Nefyodova, 2010). Also, the investment intensity is graded in three components, namely: past intensity, which characterizes the intensity of previously implemented investments; current intensity, which defines the pace of economic development and provides an opportunity to predict additional volumes of investments; future intensity orienting the planning of the whole investment process (Valinurova, Kazakova \& Iskhakova, 2012).

\section{A mathematical formalization of the investment climate components}

Considering the research study of A. Damodaran (2012) that the investment climate is reflected by the ratio of the investment supply to investment demand,

Table 1

Formulas of calculation of investment climate indicators

\begin{tabular}{|c|c|}
\hline Component & Formula of calculation \\
\hline \multirow[b]{2}{*}{$\begin{array}{l}\text { Investment attractiveness } \\
\text { (investment supply) }\end{array}$} & $L_{I A}=\sqrt{\left.\frac{G D P-B D-W-T_{P I}}{(I-B I)_{C}}\right)^{2}} * 100 \geq 10 \%$ \\
\hline & $\begin{array}{l}\text { where: } \mathrm{L}_{\mathrm{IA}} \text { - the level of the investment attractiveness of the country, \%; } \\
\text { GDP - gross domestic product, c. u.; } \\
\mathrm{BD} \text { - budget deficit volume, c. u.; } \\
\text { W - the amount of wages of hired workers, c. u.; } \\
\mathrm{T}_{\mathrm{PI}}-\text { net taxes on production and imports, c. u.; } \\
(\mathrm{I}-\mathrm{BI})_{C} \text { - the result of the subtraction between total and budget investments of the country, c. u. }\end{array}$ \\
\hline \multirow{2}{*}{$\begin{array}{l}\text { Investment intensity (investment } \\
\text { demand) }\end{array}$} & $L_{I I}=\frac{I_{I}}{I_{I-1}} * 100 \geq 100 \%$ \\
\hline & $\begin{array}{l}\text { where: } L_{I I}-\text { the level of the investment intensity in the country, \%; } \\
I_{I}-\text { the amount of total investments in the current period, c. u.; } \\
I_{I-1} \text { - the amount of total investments in the previous period, c. u. }\end{array}$ \\
\hline \multirow[b]{2}{*}{ Investment climate } & $R_{I C}=\frac{L_{I A}}{L_{I I}} \geq 0.1$ \\
\hline & $\begin{array}{l}\text { where: } \mathrm{R}_{\mathrm{IC}} \text { - the ratio of the investment climate favourableness in the country; } \\
\mathrm{L}_{\mathrm{IA}}-\text { the level of the investment attractiveness of the country, \%; } \\
\mathrm{L}_{\mathrm{II}} \text { - the level of the investment intensity in the country, \%. }\end{array}$ \\
\hline
\end{tabular}

Source: the author's research on the basis of (Damodaran, 2012; Erlen \& Isaak, 2015, p. 159, Valinurova, Kazakova \& Iskhakova, 2012) 
let us consider the procedure for calculating these components in Table 1.

So, proceeding from the fact that L.S. Valinurova, O.B. Kazakova, and E.I. Iskhakova (2012) came to the conclusion that the threshold of the level of the investment attractiveness of the country, region, industry and/or enterprise should be at least $10.0 \%$, and B. Erlen and A.J. Isaak (2015) established that the threshold of the level of the growth rate of investments in the appropriate economic system reflecting the investment intensity should be not less than standard balanced ratio (100.0\%), the threshold of the ratio of the investment climate favourableness as the ratio of the threshold of the investment attractiveness level to the threshold of the investment intensity level should be at least 0.1 . The ratio less than 0.1 may indicate the low ability of the economic system to implement investment projects, the factors of which are usually connected with unregulated interests between subjects of the investment process and, consequently, high level of investment risks.

\section{The character of interconnections between investment attractiveness and investment intensity}

Taking into account the research studies of A. Damodaran (2012), B. Erlen and A.J. Isaak (2015), the investment intensity is characterized by the intensity not only of the allocation of investment resources in the reproduction of fixed capital but also creation of preconditions for future placements in order to capitalize the income generated by investment. In this case, the investment intensity reflects not only the dynamics of the achieved volume of investments, their sources and results, but indirectly assesses their efficiency.

Thus, based on the structuring of the evaluation of the investment intensity level, algorithms of such an evaluation can include the growth rate of funding source $\left(\mathrm{R}_{\mathrm{FS}}\right)$, based on which the investment is implemented in a particular industry of the national economy. The corresponding calculation formula is as follows:

$$
R_{F S}=\frac{\frac{F S_{F}}{I_{I}} * 100}{\frac{F S_{F-1}}{I_{I-1}} * 100} * 100 \geq 100 \%,
$$

where $\mathrm{FS}_{\mathrm{F}}$ - the amount of funding source, under which the investment activity is carried out in the current period, $\mathrm{FS}_{\mathrm{F}-1}$ - in the previous period, c. u.; $\mathrm{I}_{\mathrm{I}}-$ the amount of total investments in the current period, $\mathrm{I}_{\mathrm{I}-1}-$ in the previous period, $\mathrm{c}$. $\mathrm{u}$.

Given the above, the investment intensity characterizes the dynamics of the structure of funding sources, acting as an indicator of results of investing in the economy, which determines the ability of the national investment system to carry out the real and financial investments that materialize in the newly created factors of social production and infrastructure, and increases its level of the investment attractiveness and degree of favourable investment climate of the country.

Based on the research studies of N.M. Gulyaeva and N.K. Ryabchenko (2012), A.V. Lobunko (2010), O.P. Tishchenko (2011), the growth rate of one or another funding source reflects a current situation in the investment market, including the presence of certain types of risks.

So, the growth rate of the share of funding source at the expense of its own funds of enterprises, which is below $100.0 \%$, suggests that the state did not create appropriate conditions that would be sufficient for the effective passing of the investment process. It leads to the emergence of a number of problems that may be related: with decreasing the economic potential (low level of resource availability, lack of free land for productive investment, scientific and technological capacity and infrastructure); with general economic conditions (low rates of development of branches of material production, large volumes of unfinished construction, high level of deterioration of fixed assets, low technological level of construction base); organizational and legal factors (low level of the state decision-making capabilities; adverse conditions of movement of goods, capital, and labour; low business quality management).

The growth rate of the share of funding source at the expense of borrowed funds from financial institutions below $100.0 \%$ means the increase of the influence on the financial market of negative factors connected with limited access to loans, their high value, the low specific weight of long-term loans, high inflation.

The growth rate of the share of funding source at the expense of foreign investors' funds below $100.0 \%$ reflects the weak state influence on foreign economic activities of business entities. As a rule, it is due to the presence of unfavourable organizational and legal conditions connected with an inefficient state policy of foreign investment involvement, low level of development of the market infrastructure and competitive environment, the unfavourable influence of privatization, insignificant export opportunities, and also the insufficient volume of foreign entrepreneurial capital.

The growth rate of the share of funding source at the expense of population funds below $100.0 \%$ indicates a lack of targeted state policy towards the involvement of the population to the investment process because of the low level of public confidence in the state authorities, low income, social deformations, etc.

Similar trends in the dynamics of funding sources at the expense of state and local budgets characterize the low degree of financial participation of the state in the investment process, first of all, in terms of ensuring the economic and social development of the country. This situation is a reflection of the impact on the investment process by various negative factors, namely: political (imperfect relations between central and regional authorities, low level of social stability), organizational 
and legal (low quality of enforcement, limited awareness of the population, low efficiency of law enforcement agencies) and financial (insignificant revenue part of local budgets, opacity of their expenditures, etc.).

Thus, the investment at the expense of different funding sources affects not only the total volume of capital investments in the country but also has a huge impact on the investment attractiveness level for both national and foreign potential investors. So, an efficient investment at the expense of its own funds of enterprises increases the job creation, wages of employees and, accordingly, the revenue side of the consolidated budget, which will increase the ability of the state to provide the investment support for innovation projects. An efficient investment at the expense of financial institutions' funds facilitates the effective process of lending, which will increase the level of trust in banks by business entities, bank profitability and, accordingly, bank liquidity. An efficient investment at the expense of foreign investors' funds will promote the development of transnational corporations, which will, accordingly, strengthen foreign relations of Ukraine. An efficient investment at the expense of the population funds promotes the population to be interested in investment projects, the implementation of which may positively impact on the economic and social development of the country, which motivates individuals to find a high paying job and, accordingly, reduces the level of unemployment. Finally, an efficient investment at the expense of the state and local budgets will help reduce the level of investment risks of non-state investors, efficiently allocate and distribute the gross domestic product based on the strategic elaboration of a budget plan for the next year and, consequently, regulate the tax burden on both the population and enterprises, including those who are engaged in innovation activities.

\section{Analysis of the nature of the investment climate in Ukraine}

It is obvious that the investment climate in Ukraine during thelast five years has turned out to be unfavourable due to a number of economic disproportions in relations between the state and business entities. This is manifested by the fact that the state tries to provide investment support not constantly but only when the investment intensity of business entities is reduced (Table 2).

So, the budget investment intensity of the state from 2012 to 2014 was at a level lower than $100 \%$, while the corresponding level of private enterprises exceeded the threshold. In 2015, under the conditions of reduction of the investment intensity level of private enterprises to $95.78 \%$, compared to 2014 (110.54\%), and increase in the corresponding growth rate of its share in 2016 to $102.60 \%$, the level of budget investment intensity of the state sharply increased to $202.96 \%$, compared to 2014 (51.43\%), when in 2016 the corresponding growth rate of its share fell to $101.79 \%$, despite exceeding the threshold. A similar situation can be observed with trends in the growth rate of the share of capital investments at the expense of local budgets. In most cases, the corresponding phenomenon can be explained by the fact that the investment support from the state causes a side effect on business entities, in particular, private enterprises. That is, during the period of economic stability of private enterprises, the state does not try to stimulate them to implement investments projects, reducing investments risks, while during the period of economic recession the state tries to provide an investment support as much as possible. In this case, private enterprises lose the ability to carry out investment activities effectively without the state interference (the impact of displacement).

A completely different situation can be traced to the investment intensity of foreign investors. Here, in conditions of stable investment environment at private enterprises, foreign investors in some sense begin to exceed their authority, trying to conclude contracts with national producers as much as possible, and then gradually oust them from Ukrainian market. It is indicated by a substantial increase in the investment intensity level of foreign investors by the end of 2014 to $140.99 \%$, and also a slowdown in the investment intensity level of private enterprises in 2015 to $95.78 \%$. At the same time, a similar situation often causes a lack of motivation of the population to implement investment projects, as indicated by a decline in investment intensity level of the population by 2014 to $94.98 \%$, compared with 2013 (121.34\%). All of this gradually decreases a confidence of national producers to foreign investors as indicated by reducing the investment intensity level of foreign investors by the end of 2016 to $91.32 \%$. In addition, it reduces the ability of the population to invest, as indicated by a decline in the investment intensity level of the population in 2016 to $71.15 \%$, when in 2015 the corresponding growth rate of its share increased to $116.47 \%$.

At the same time, the investment intensity of financial institutions, in particular banks, during the analysed period had moderate fluctuations. These fluctuations can be equated with the phenomenon in which, in a context of diminishing relations with foreign investors, business entities prefer to strengthen relations with financial institutions (banks). This is indicated by the sharp decline in the investment intensity level of financial institutions by the end of 2014 to $64.89 \%$ and a gradual increase of the corresponding growth rate by the end of 2016 to $99.37 \%$. In addition, the investment intensity level of financial institutions for almost the whole analysed period was at a level below the threshold. It suggests that the unregulated relationships between subjects of investment process led to a gradual decline in the financial statements of private enterprises and 
Table 2

Indicators of the investment climate in Ukraine from 2012 to 2016

\begin{tabular}{|c|c|c|c|c|c|c|}
\hline No & Indicator/year & 2012 & 2013 & 2014 & 2015 & 2016 \\
\hline 1 & Gross domestic product, mln UAH & 1459096 & 1522657 & 1586915 & 1988544 & 2385367 \\
\hline 1.1 & Net taxes on production and imports, mln UAH & -10785 & 2937 & -5 & 16754 & 7205 \\
\hline 1.2 & The amount of wages of hired workers, mln UAH & 705837 & 730653 & 734943 & 777646 & 873829 \\
\hline 2 & Budget deficit volume, mln UAH & 50786 & 63590 & 72030 & 30898 & 61801 \\
\hline \multirow{3}{*}{3} & Total capital investments, mln UAH & 293692 & 267728 & 219420 & 273116 & 359216 \\
\hline & at the expense of the state budget & 17141 & 6498 & 2739 & 6920 & 9264 \\
\hline & at the expense of local budgets & 9149 & 7219 & 5918 & 14260 & 26817 \\
\hline \multirow{2}{*}{3.1} & The share at the expense of its own funds of private enterprises, $\%$ & 59.73 & 63.75 & 70.47 & 67.50 & 69.25 \\
\hline & The growth rate of funding source, $\%$ & 101.96 & 106.73 & 110.54 & 95.78 & 102.60 \\
\hline \multirow{2}{*}{3.2} & The share at the expense of financial institutions' funds, $\%$ & 17.06 & 15.27 & 9.91 & 7.59 & 7.55 \\
\hline & The growth rate of funding source, $\%$ & 104.78 & 89.50 & 64.89 & 76.65 & 99.37 \\
\hline \multirow{2}{*}{3.3} & The share at the expense of foreign investors' funds, $\%$ & 1.72 & 1.82 & 2.57 & 3.00 & 2.74 \\
\hline & The growth rate of funding source, $\%$ & 62.00 & 106.22 & 140.99 & 116.60 & 91.32 \\
\hline \multirow{2}{*}{3.4} & The share at the expense of population funds, $\%$ & 8.73 & 10.59 & 10.06 & 11.71 & 8.33 \\
\hline & The growth rate of funding source, $\%$ & 115.88 & 121.34 & 94.98 & 116.47 & 71.15 \\
\hline \multirow{2}{*}{3.5} & The share at the expense of the state budget, $\%$ & 5.84 & 2.43 & 1.25 & 2.53 & 2.58 \\
\hline & The growth rate of funding source, $\%$ & 82.47 & 41.59 & 51.43 & 202.96 & 101.79 \\
\hline \multirow{2}{*}{3.6} & The share at the expense of local budgets, $\%$ & 3.12 & 2.70 & 2.70 & 5.22 & 7.47 \\
\hline & The growth rate of funding source, $\%$ & 92.00 & 86.56 & 100.03 & 193.59 & 142.98 \\
\hline \multirow{2}{*}{3.7} & The share at the expense of other funds, $\%$ & 3.82 & 3.45 & 3.05 & 2.44 & 2.09 \\
\hline & The growth rate of funding source, $\%$ & 87.27 & 90.36 & 88.43 & 80.16 & 85.38 \\
\hline 4 & The subtraction between total and budget investments, mln UAH & 267402 & 254011 & 210763 & 251936 & 323135 \\
\hline 5 & The investment attractiveness level, \% & 2.67 & 2.86 & 3.70 & 4.62 & 4.46 \\
\hline 6 & The investment intensity level, \% & 112.99 & 91.16 & 81.96 & 124.47 & 131.53 \\
\hline 7 & The ratio of the investment climate favourableness & 0.02 & 0.03 & 0.05 & 0.04 & 0.03 \\
\hline
\end{tabular}

Source: the author's combination and calculations according to websites: State Statistics Service of Ukraine; Price of the State (2016)

living standard of the population, weakening of relations with foreign investors, and increase in tax burden by the state on the subjects of investment process in order to replenish the revenue side of the budget. All of this increased the level of bank risks of non-return of investment loans by subjects of the investment process and obtaining large losses of banks.

Also, the growth rate of the share of capital investments at the expense of other funds for the whole analysed period was below the threshold. It may indicate that the level of the investment intensity of all institutions except private enterprises, banks, foreign investors, and individuals was low and had moderate fluctuations. Such institutions may include various types of innovation institutes, including technological policies, technological parks, business incubators, and other institutions that promote the development of innovation infrastructure in the country. However, unfortunately, in Ukraine, there is an absence of a sufficient number of innovation institutions that could provide sufficient innovation infrastructure, which, accordingly, negatively affects the investment attractiveness and, consequently, investment climate.

Thus, an increase in the overall investment intensity level, if there is an appropriate imbalance in the relations between the subjects of the investment process, may negatively affect the investment climate in the country.
It is indicated by a rather low ratio of investment climate favourableness in 2012 (0.02) with the investment intensity level of $112.99 \%$, and also gradual decrease in the corresponding ratio from 2014 to 2016 (0.05 and 0.03 ), with the increase of the investment intensity level for this period from $81.96 \%$ to $131.53 \%$ respectively. However, a decrease in the overall investment intensity level may also negatively affect the level of investment attractiveness of the country and, accordingly, worsen the investment climate. For example, from 2012 to 2014, the trend of increasing the investment attractiveness level in Ukraine was minor (from $2.67 \%$ to $3.70 \%$ ), while the decline in investment intensity level during this period was significant (from $112.99 \%$ to $81.96 \%$ respectively).

So, a significant lack of threshold value of the investment attractiveness level is the main factor of the unfavourable investment climate in Ukraine.

In 2012, the high tax burden negatively influenced the level of investment attractiveness of Ukraine, due to which the lack of threshold value of its level was quite significant $(2.67 \%)$. According to data from official Website of Price of the State (2016), due to the increase in the tax burden, the state was forced to increase the amount of subsidies as can be seen on trends of net taxes on production and imports negatively amounted to 10785 million UAH. It significantly contributed to 
the increase in the budget deficit volume (up to 50786 million UAH), compared with previous periods. All of this forced the state to lower the level of budget investment intensity, as indicated by the fall in the growth rate of the share at the expense of the state budget in 2013 to $41.59 \%$, compared with 2012 (82.47\%), when in 2014 there was a slight increase to $51.43 \%$. At the same time, the growth rate of the share at the expense of local budgets decreased in 2013 to $86.56 \%$, compared to 2012 (92.00\%), while in 2014 this indicator increased to $100.03 \%$, exceeding the threshold. Thus, the increase in the investment climate in 2014 to 0.05 does not say about the economic and social improvement of Ukraine, since the investment intensity level has fallen to $81.96 \%$, while the investment attractiveness level has only increased (up to $3.70 \%$ ) due to the government's effective tax burden adjustment when the indicator of net taxes on production and imports reached a balanced level (-5 million UAH).

Meanwhile, despite the fact that the investment intensity of the state significantly increased in 2015, as evidenced by a significant increase in the share at the expense of the state budget (up to 202.96\%) and local budgets (up to 193.59\%), and in 2016 due to a significant increase in the volume of funds at the expense of the state (up to 9264 million UAH) and local budgets (up to 26817 million UAH), compared with 2015 (6920 million UAH and 14260 million UAH respectively), remained at the level above the threshold, the subtraction between total capital investments and budget funds by the end of 2016 has only risen. The corresponding situation negatively affected the investment climate in the country, reducing its ratio to 0.03 , because, despite the increase of state support, which in our case only has a side effect on the activities of non-state potential investors, the level of investment risks for the relevant group of investors has significantly increased. Thus, despite a significant increase in the investment intensity level in 2016 (up to $131.53 \%$ ), the investment attractiveness level dropped to $4.46 \%$. It was especially influenced by an increase in the budget deficit and also in tax burden, despite the fact that the amount of net taxes on production and imports decreased to 7205 million, UAH compared with 2015 (16754 million $\mathrm{UAH})$. All of this contributed to deteriorating the investment climate in Ukraine.

\section{Conclusions}

The investment climate is determined by the ratio of the supply of investment resources for potential investors (investment attractiveness) to the demand for investment resources by recipients of investments (investment intensity). Over the past five years, the investment climate in Ukraine has been unfavourable. This phenomenon was characterized by the existence of a number of economic imbalances in relations between the subjects of the investment process, namely: private enterprises, financial institutions, population, foreign investors, innovation institutes, and state. In order to improve the investment climate in Ukraine, the government should review the tax legislation, in particular, the Tax Code of Ukraine, the enactment of which abolished almost all the tax incentives for technological parks of Ukraine, national producers, and foreign investors, and also caused the stretching of the time of participation in the amortization in the calculation of income tax. Thus, it is necessary to introduce at least the abolished tax privileges. In turn, this introduction requires including the provisions on transparency of investment, profit from investment, conclusion and termination of investment contracts. It is needed in order to prevent, firstly, the absorption by transnational corporations of national producers, and secondly, - the illegal flow of funds in offshore zones for avoiding payments of taxes on investment activities.

\section{References:}

Damodaran, A. (Ed.). (2012). Investment Valuation: Tools and Techniques for Determining the Value of Any Asset (3rd ed.). New Jersey: WILEY, 973 p. Retrieved from: https://books.google.com.ua/

Erlen, B., \& Isaak, A. J. (2015). BWL-Kennzahlen / Business Ratios. Weinheim: WILEY-VCH Verlag GmbH \& Co. KGaA, 311 p. Retrieved from: https://books.google.com.ua/

Grynyova, V. M., Koyuda, V. O., Lepeyko, T. I., Koyuda O. P. (2008). Investuvannya [Investment]. Kyiv: Znannya, 452 p. Retrieved from: http://westudents.com.ua/knigi/207-nvestuvannya-grinova-vm.html (in Ukrainian)

Gulyaeva, N. M., Ryabchenko, N. K. (2012). Sutnisni oznaky investytsiynoyi pryvablyvosti pidpryyemstva: faktorna pryroda formuvannya [Essential signs of the investment attractiveness of enterprise: factor nature of formation]. Bulletin of the National University of Zaporizhya. Series: "Economic Sciences", no. 1 (13), pp. 22-28.

Lobunko, A. V. (2010). Systema pokaznykiv regionalnoyi efektyvnosti investytsiy v rozvytok promyslovykh pidpryyemstv [System of indicators of the regional efficiency of investments in the development of industrial enterprises]. Sustainable Development of Economy: All-Ukrainian Scientific and Production Journal, no. 2, pp. 99-104. Mayo, H. B. (Ed.). (2014). Investments: An Introduction. (11th ed.). The College of New Jersey: SWCL, 795 p. Retrieved from: https://books.google.com.ua/

Nefyodova, Y. V. (2010). Vyznachennya teoretychnykh zasad kharakterystyky investytsiynogo seredovyshcha [Determination of the theoretical basis of the investment environment characteristics]. Torgivlya i rynok Ukrayiny: Tematychnyy zbirnyk naukovykh prats' [Trade Market of Ukraine: Thematic Collection of Scientific Works], vol. 29, pp. 432-440. Retrieved from: http://bo0k.net/index.php?p=achapter\&bid=1320\&chapter=1 
Price of the State (2016). Budget of Ukraine. Retrieved from: http://www.cost.ua/budget/

State Statistics' Service of Ukraine. Economic statistics / Economic activities / Capital investments. Retrieved from: http://www.ukrstat.gov.ua/

State Statistics' Service of Ukraine. Economic statistics / National accounts / Annual national accounts. Retrieved from: http://www.ukrstat.gov.ua/

Tishchenko, O. P. (2011). Regionalni dysproportsiyi: sutnist, metodologiya vyznachennya ta otsinka [Regional disproportions: ess

ence, methodology for definition and evaluation]. Economic Theory, no. 4, pp. 55-64.

Valinurova, L. S., Kazakova, O. B., Iskhakova, E. I. (2012). Investirovaniye. Upravleniye investitsionnymi protsessami innovatsionnoy ekonomiki [Investment. Management of investment processes of innovative economy]. Ufa: BAPAM, 78 p. (in Russian) 